\title{
Production of $\beta$-(1,3)-glucanases by Trichoderma harzianum Rifai: Optimization and Application to Produce Gluco-oligosaccharides from Paramylon and Pustulan
}

\author{
Ellen C. Giese ${ }^{1,2}$, Robert F. H. Dekker ${ }^{2 *}$, Aneli M. Barbosa ${ }^{2,3}$, Maria de Lourdes Corradi da Silva ${ }^{4}$ and Roberto da Silva ${ }^{1}$ \\ ${ }^{1}$ Departamento de Química e Ciências Ambientais, Universidade Estadual Paulista, IBILCE, São José do Rio Preto, São Paulo, Brazil \\ ${ }^{2}$ Biorefining Research Institute, Lakehead University, Thunder Bay, ON, Canada P7B 5E1 \\ ${ }^{3}$ Departamento de Bioquímica e Biotecnologia, CCE, Universidade Estadual de Londrina, UEL, Londrina, Paraná, Brazil \\ ${ }^{4}$ Departamento de Física, Química e Biologia, Universidade Estadual Paulista, FCT, Presidente Prudente, São Paulo, Brazil
}

\begin{abstract}
$\beta$ - $(1 \rightarrow 3)$-Glucanases were produced by Trichoderma harzianum Rifai PAMB-86 cultivated on botryosphaeran in a bench-fermenter and optimised by the response surface method. Maximal enzyme titres occurred at 5 days, initial $\mathrm{pH} 5.5$ and aeration of $1.5 \mathrm{vvm}$. $\beta-(1 \rightarrow 3)$-The $\beta$-glucanolytic enzyme complex produced by $T$. harzianum Rifai PAMB86 was fractionated by gel filtration into 2 fractions (F-I, F-II), and employed to produce gluco-oligosaccharides from algal paramylon $((1 \rightarrow 3)-\beta-D$-glucan) and lichen pustulan $((1 \rightarrow 6)-\beta$-D-glucan). Both enzymes attacked paramylon to the extent of $\sim 15-20 \%$ in 30 min releasing glucose and laminaribiose as major end-products, and laminarioligosaccharides of degree of polymerization (DP) $\geq 3$. Only F-I degraded pustulan resulting in $\sim 2 \%$ degradation at $30 \mathrm{~min}$, with glucose, gentiobiose and gentio-oligosaccharides of DP $\geq 4$ as major products. The difference in the nature of the hydrolysis products can be explained by the substrate specificities of each enzyme fraction, and the structural differences of the $\beta$-D-glucans attacked.
\end{abstract}

Keywords: Trichoderma harzianum PAMB-86; $\quad \beta-(1 \rightarrow 3)$ Glucanases; Response surface method; Paramylon; Lichen Pustulan; Gluco-oligosaccharides

\section{Introduction}

Many fungal $\beta$-D-glucans have been described that possess biological activities including immunomodulation [1]. Modification of polysaccharides has contributed to the development of new industrial applications for these biopolymers in a variety of commercial sectors such as pharmaceuticals, cosmetics and foods [2,3]. Modification through hydrolysis produces gluco-oligosaccharides which have demonstrated health benefits that influence the immune system, and are recognized as having biological response modifying activities [4,5].

Paramylon, a storage (13)- $\beta$-D-glucan derived from the alga, Euglena gracilis, consists of a non-ramified chain constituted of D-glucose units [6]. Pustulan is a linear $(1 \rightarrow 6)-\beta$-D-Glucan usually isolated from lichens [7], but these $\beta$-D-glucans are also present in fungi [8], where they exist as a cell wall component. More recently, water-soluble exocellular $(1 \rightarrow 6)-\beta$-D-glucans have been reported for several Botryosphaeria rhodina strains [9], and Guignardia citricarpa [8]. Pustulan is commonly used as a substrate for assaying $\beta-1(\rightarrow 6)$ glucanase activity [10], and as carbon source in screening for this type of enzyme activity [11].

$\beta$-( $1 \rightarrow 3)$-Glucanases have been used to depolymerize $(1 \rightarrow 3)$ $(1 \rightarrow 6)-\beta$-D-glucans to obtain degraded fragments that possess biological and functional properties for use as pharmaceuticals, and inclusions as prebiotics in foods and beverages $[4,12,13]$. The $\beta-(1 \rightarrow 3)-$ glucanases are predominantly of two enzyme types: exo- (EC 3.2.1.58) and endo- (EC 3.2.1.39) acting that specifically attack $\beta$-( $1 \rightarrow 3)$-linked $D$-glucans [14]. Accessory enzymes that complement the key enzymes involved in the degradation of the $(1 \rightarrow 3)(1 \rightarrow 6)-\beta$-D-glucans include the $\beta$-( $1 \rightarrow 6)$-glucanases (EC 3.2.1.75) and $\beta$-glucosidases (EC 3.2.1.21); each produced by several fungal species $[15,16]$. Trichoderma species have been widely investigated as bio-control agents and are renowned to produce hydrolytic enzymes that act synergistically on plant and fungal cell wall polysaccharides. Enzymes from Trichoderma species, and esp. T. harzianum, have been used to degrade extracellular $(1 \rightarrow 3)$ $(1 \rightarrow 6)-\beta$-D-glucans to produce gluco-oligosaccharides $[10,17]$.

In this work, we report on the production of $\beta$ - $(1 \rightarrow 3)$-glucanases by Trichoderma harzianum Rifai PAMB-86 cultivated in a fermenter on $(1 \rightarrow 3)(1 \rightarrow 6)-\beta$-D-glucan (botryosphaeran) as sole carbon source, and their optimization by the response surface method (RSM). The $\beta$ - $(1 \rightarrow 3)$-glucanases produced were partially fractionated and employed to enzymatically hydrolyze paramylon and pustulan. Studies involving specific $\beta$-glucanases in the hydrolysis of algal and lichen $\beta$-glucans are important to understand the nature of the hydrolysis reactions involved, and to develop new strategies to obtain glucooligosaccharides on a large scale for biotechnological applications.

\section{Material and Methods}

\section{Materials}

Paramylon (an unbranched ( $1 \rightarrow 3)-\beta$-D-glucan from Euglena gracilis) was purchased from Fluka. Pustulan $((1 \rightarrow 6)-\beta-D$-glucan $)$ a kind gift from Professor Philip Gorin (Universidade Federal do Paraná, Curitiba-PR, Brazil), was isolated from the lichen, Actinogyra muehlenbergii [7]. Laminarin (Laminaria digitata), laminaribiose,

*Corresponding author: Dr Robert F.H. Dekker, Biorefining Research Institute Lakehead University, Thunder Bay, ON, Canada P7B 5E1, Tel: 1+(807) 343-8844 Fax: 1+(807) 343-8240; E-mail: rdekker@lakeheadu.ca

Received January 12, 2012; Accepted February 15, 2012; Published February 18,2012

Citation: Giese EC, Dekker RFH, Barbosa AM, da Silva MLC, da Silva R (2011) Production of $\beta-(1,3)$-glucanases by Trichoderma harzianum Rifai: Optimization and Application to Produce Gluco-oligosaccharides from Paramylon and Pustulan. Ferment Technol 1:102. doi:10.4172/2167-7972 .1000102

Copyright: ( 2011 Giese EC, et al. This is an open-access article distributed unde the terms of the Creative Commons Attribution License, which permits unrestricted use, distribution, and reproduction in any medium, provided the original author and source are credited. 
Citation: Giese EC, Dekker RFH, Barbosa AM, da Silva MLC, da Silva R (2011) Production of $\beta$-(1,3)-glucanases by Trichoderma harzianum Rifai: Optimization and Application to Produce Gluco-oligosaccharides from Paramylon and Pustulan. Ferment Technol 1:102. doi:10.4172/21677972.1000102

Page 2 of 5

laminaritriose, gentiobiose and $p$-nitrophenyl- $\beta$-D-glucopyranoside ( $p$-NPG) were purchased from Sigma-Aldrich. Botryosphaeran (a $(1 \rightarrow 3)(1 \rightarrow 6)-\beta-D$-glucan) was obtained from Botryosphaeria rhodina MAMB-05 according to Barbosa et al. [18].

\section{Microorganism and culture conditions}

Trichoderma harzianum Rifai (isolate PAMB-86) was obtained from decaying peroba rosa wood (Aspidosperma spp.) and maintained on xylose-agar at $4^{\circ} \mathrm{C}[11]$ incorporating Vogel minimal salts medium (VMSM) [19]. T. harzianum Rifai PAMB-86 conidia were used to inoculate $\left(1 \times 10^{8}\right.$ spores/flask) three $125 \mathrm{ml}$ Erlenmeyer flasks containing $25 \mathrm{ml}$ liquid medium comprising VMSM and glucose (10 $\mathrm{g} / \mathrm{l}$ ) during $72 \mathrm{~h}, 180 \mathrm{rpm}$ at $28^{\circ} \mathrm{C}$. The mycelium resulting was used as inoculum in fermenter-based experiments. The fungal isolate was cultivated in a laboratory fermenter of 2.51 capacity equipped with a $\mathrm{pH}$ electrode, and facilities for control of agitation and aeration (Technal, Brazil), and was operated in a batch continuous mode. The fermenter was equipped with four removable standard baffles, and a top driven agitator shaft mounted with three standard blades (Rushton impellers). Fermentation was carried out using $600 \mathrm{ml}$ medium comprising VMSM and botryosphaeran $(1.5 \mathrm{~g} / \mathrm{l})$ as sole carbon source at $28^{\circ} \mathrm{C}$ and $120 \mathrm{rpm}$. Aeration, initial $\mathrm{pH}$ and time of growth for the production of $\beta$-( $1 \rightarrow 3)$-glucanases by T. harzianum Rifai PAMB-86, were used as variables in the statistical experimental design outlined below. Extracellular fluid (ECF) was recovered following centrifugation (7000xg/10 min), exhaustively dialyzed against deionised water at $4^{\circ} \mathrm{C}$, and used as the source of enzyme.

\section{Enzyme assays}

$\beta$-Glucanase activity was determined using the polysaccharides: laminarin $(\beta-(1 \rightarrow 3)$-glucanase $)$ and pustulan $(\beta-(1 \rightarrow 6)$-glucanase $)$ according to Giese et al. [10]. The hydrolysis products released were measured as reducing sugars [20]. The unit of each $\beta$-glucanase activity was defined as the number of $\mu$ mol reducing sugars produced/ min. $\beta$-Glucosidase activity was measured against $p$-nitrophenyl- $\beta$ glucopyranoside $(15 \mathrm{mM})$ as substrate, and incubated at $55^{\circ} \mathrm{C}$ for 20 min [10]. The unit of $\beta$-glucosidase activity was defined as the number of $\mu \mathrm{mol} p$-nitrophenol liberated/min.

\section{Analytical procedures}

Hydrolysis products arising from various glucans were measured by the reducing sugars method [20]. Glucose from gluco-oligosaccharides was measured by the glucose oxidase method using a kit (Glicose Enz Color reagent kit; Bio Diagnóstica, Curitiba, Brazil).

\section{HPAEC/PAD analysis of enzymatic hydrolysates}

Following enzymatic hydrolysis, undigested polymeric material remaining in the hydrolysates was removed by precipitation with 3 volumes of ethanol [10]. The supernatant was recovered by centrifugation (7000x $\mathrm{g} / 10 \mathrm{~min}$ ), and the ethanol evaporated under vacuum. The resulting syrup was re-solubilized in water, and used for determination of reducing sugars, and aliquots of $0.025 \mathrm{ml}$ taken for sugar analysis by High Performance Anionic Exchange Chromatography with Pulsed Amperometric Detection (HPAEC/PAD) on a Dionex Chromatograph DX 500. Mono- and oligo- saccharides were separated on a CarboPac PA100 (Dionex Chromatography) column $(4 \times 250$ $\mathrm{mm}$ ) equipped with a PA-100 guard column at a flow rate of $1.0 \mathrm{ml} /$ min. The column was equilibrated in $0.1 \mathrm{M} \mathrm{NaOH}(97 \%)$ and $0.5 \mathrm{M}$ sodium acetate $(3 \%)$. After $15 \mathrm{~min}$, a linear $0-0.25 \mathrm{M}$ concentration gradient of sodium acetate was applied over a 70 min interval while the concentration of $\mathrm{NaOH}$ remained at $0.1 \mathrm{M}$. Sugar quantification was carried out from peak area measurements using response factors obtained from authentic standard sugars, and identified by their retention times $\left(\mathrm{T}_{R} \pm \mathrm{SD} \mathrm{min}\right)$ : glucose $(2.93 \pm 0.06 \mathrm{~min})$, gentiobiose $(4.57 \pm 0.21 \mathrm{~min})$, laminaribiose $(7.12 \pm 0.80 \mathrm{~min})$ and laminaritriose (17.34 $\pm 0.20 \mathrm{~min})$. Peaks exiting the chromatography column after 20 min were considered oligosaccharides of DP 4 and greater than 4 .

\section{Factorial design and analysis}

Fermentation conditions to optimise $\beta$ - $(1 \rightarrow 3)$-glucanase production by T. harzianum Rifai PAMB-86 were studied as variables in a factorial design and analysis by the response-surface method (Table 1). The independent variables were $x_{1}=$ aeration (vvm), $x_{2}=$ initial $\mathrm{pH}$, and $x_{3}$ $=$ time of growth. The level of these variables and the variation levels for experimental studies on $\beta$ - $(1 \rightarrow 3)$-glucanase production $\left(Y_{1}=\mathrm{U} /\right.$ $\mathrm{ml}$ ) are shown in Table 1. Analysis of variance (ANOVA) and multiple regression analysis were performed using STATISTICA Version 6.

\section{Fractionation of $\beta$-glucanolytic complex from $T$. harzianum Rifai PAMB-86}

Extracellular fluid $(600 \mathrm{ml})$ containing the enzyme was lyophilized following centrifugation to remove the mycelium. Lyophilized ECF was dissolved in $20 \mathrm{mM}$ sodium acetate buffer ( $\mathrm{pH}$ 5.0) and applied to a column of Sephadex G-100 $(2.5 \times 90 \mathrm{~cm}$, Pharmacia Biotech, Sweden), and eluted with $20 \mathrm{mM}$ sodium acetate buffer ( $\mathrm{pH}$ 5.0) at a flow rate of $15 \mathrm{ml} / \mathrm{h}$. Fractions of $2.5 \mathrm{ml}$ were collected and analyzed for $\beta-(1 \rightarrow 3)$ glucanase, $\beta$ - $(1 \rightarrow 6)$-glucanase and $\beta$-glucosidase activities. Two fractions were isolated (designated F-I and F-II), and used as the source of enzyme to hydrolyse paramylon and pustulan. All fractionation steps were performed at $4^{\circ} \mathrm{C}$.

\section{Results and Discussion}

\section{Production of $\beta$ - $(1 \rightarrow 3)$-glucanases by Trichoderma harzianum Rifai PAMB-86}

Production of microbial $\beta$ - $(1 \rightarrow 3)$-glucanases are strongly

\begin{tabular}{|c|c|c|c|c|c|}
\hline \multirow[t]{2}{*}{ Experimental run } & \multicolumn{3}{|c|}{$\begin{array}{l}\text { Variables in } \\
\text { coded levels }\end{array}$} & \multicolumn{2}{|c|}{$\begin{array}{c}\beta-(1 \rightarrow 3) \text {-Glucanase activity }(\mathrm{U} / \\
\mathrm{ml})\end{array}$} \\
\hline & $x_{1}$ & $x_{2}$ & $x_{3}$ & Experimental & Predicted \\
\hline 1 & -1 & -1 & -1 & 0.69 & 0.62 \\
\hline 2 & -1 & -1 & +1 & 1.88 & 1.88 \\
\hline 3 & -1 & +1 & -1 & 0.92 & 0.93 \\
\hline 4 & -1 & +1 & +1 & 1.52 & 1.58 \\
\hline 5 & +1 & -1 & -1 & 0.94 & 0.95 \\
\hline 6 & +1 & -1 & +1 & 1.96 & 2.02 \\
\hline 7 & +1 & +1 & -1 & 0.60 & 0.66 \\
\hline 8 & +1 & +1 & +1 & 0.72 & 1.11 \\
\hline 9 & +1 & 0 & +1 & 3.71 & 3.46 \\
\hline 10 & 0 & +1 & +1 & 1.63 & 1.37 \\
\hline 11 & +1 & +1 & 0 & 1.72 & 1.46 \\
\hline 12 & 0 & 0 & 0 & 3.65 & 3.71 \\
\hline 13 & 0 & 0 & 0 & 3.52 & 3.71 \\
\hline \multirow{2}{*}{ Factor } & \multicolumn{5}{|c|}{ Real levels } \\
\hline & \multicolumn{2}{|c|}{-1} & & \begin{tabular}{l|l}
0 \\
0
\end{tabular} & +1 \\
\hline$x_{1}$, aeration (vvm) & \multicolumn{2}{|c|}{1.0} & & 1.5 & 2.0 \\
\hline$x_{2}$, initial $\mathrm{pH}$ & \multicolumn{2}{|c|}{3.0} & & 5.5 & 8.0 \\
\hline$x_{3}$, time of growth (days) & \multicolumn{2}{|c|}{2} & & 5 & 8 \\
\hline
\end{tabular}

Table 1: A central composite design [30] defining conditions for aeration, initial $\mathrm{pH}$ and time of growth on the production of $\beta-(1 \rightarrow 3)$-glucanases by Trichoderma harzianum Rifai PAMB-86. 
Citation: Giese EC, Dekker RFH, Barbosa AM, da Silva MLC, da Silva R (2011) Production of $\beta$-(1,3)-glucanases by Trichoderma harzianum Rifai: Optimization and Application to Produce Gluco-oligosaccharides from Paramylon and Pustulan. Ferment Technol 1:102. doi:10.4172/21677972.1000102

Page 3 of 5

influenced by the level of $\beta$-D-glucan present as inducer, and the types of glucosidic linkages present in the $\beta$-glucans used as carbon sources [21-24]. In a previous study, production of $\beta-(1 \rightarrow 3)$-glucanases by $T$. harzianum Rifai grown on botryosphaeran $(\mathrm{a}(1 \rightarrow 3)(1 \rightarrow 6)-\beta$-D-glucan from B. rhodina MAMB-05 [23] was optimized in shake-flasks. The results showed that production of $\beta$ - $(1 \rightarrow 3)$-glucanases was dependent upon the concentration of botryosphaeran and the time of growth, and highest enzyme titres obtained were $1.2 \mathrm{U} / \mathrm{ml}$. A statistical mixturedesign indicated a synergistic effect of botryosphaeran on $\beta-(1 \rightarrow 3)$ glucanases production by $T$. harzianum Rifai in combination to glucose and lactose as a mixture of carbon sources [24]. It was impractical to increase the botryosphaeran concentration in the nutrient medium in attempts to enhance enzyme titres as this exopolysaccharide is sparingly soluble in water (limit of $3 \mathrm{~g} / \mathrm{l}$ ), and aqueous solutions formed are rather viscous and difficult to manage. Instead, fermentation variables such as initial $\mathrm{pH}$ and aeration rate were evaluated in a $2.5 \mathrm{l}$ fermenter $(600 \mathrm{ml})$ to improve $\beta$ - $(1 \rightarrow 3)$-glucanase titres by $T$. harzianum Rifai PAMB-86 when cultivated on botryosphaeran. Enzyme production was optimised by the response surface method.

Through multiple regression analysis of the experimental data, a second-order polynomial equation was obtained for $\beta-(1 \rightarrow 3)$-glucanase production (Equation 1).

$$
\hat{Y}_{1}=3,71294+0,42793 x_{3}-1,89259 x_{2}^{2}
$$

Linear-effect terms of the variables $x_{1}$ and $x_{2}$ and squared-effect terms of the variables $x_{1}$ and $x_{2}$ were discarded as being non-significant. According to the results, an intercept was significant indicating that the central-points (aeration, $1.5 \mathrm{vvm}$; initial $\mathrm{pH}, 5.5$; and $5 \mathrm{~d}$ growth) were correctly chosen. The variable more important for $\beta$ - $(1 \rightarrow 3)$-glucanase production by $T$. harzianum Rifai PAMB- 86 was the initial $\mathrm{pH}$ followed by the time of growth. The analysis of variance (ANOVA) showed the lack-of-fit $(p>0.05)$ was not significant, indicating that the model was predictive (Table 2$)$. The experimental and predicted $\beta-(1 \rightarrow 3)$ glucanase activities were in agreement (Table 1). The R-squared value implied $97 \%$ of the variability in the observed response values could be explained by the model, or by experimental factors and their interactions. The pure error was low, indicating good reproducibility of the experimental data.

Statistical analysis by RSM has also been successfully employed by Donzelli et al. [25] to optimise the production of $\beta-(1 \rightarrow 3)$ glucanases by Trichoderma atroviride in shake-flask cultivation using

\begin{tabular}{|l|c|c|c|c|c|}
\hline Source of variation & $\begin{array}{c}\text { Sum of } \\
\text { squares }\end{array}$ & $\begin{array}{c}\text { Degrees of } \\
\text { freedom }\end{array}$ & Mean square & F-test & $p$ \\
\hline Aeration, $\mathrm{X}_{1}(\mathrm{~L})$ & 0.0106 & 1 & 0.0106 & 1.1745 & 0.4744 \\
\hline Aeration, $\mathrm{X}_{1}(\mathrm{Q})$ & 0.0007 & 1 & 0.0007 & 0.0805 & 0.8240 \\
\hline Initial $\mathrm{pH}, \mathrm{X}_{2}(\mathrm{~L})$ & 0.1969 & 1 & 0.1969 & 21.8204 & 0.1342 \\
\hline Initial $\mathrm{pH}, \mathrm{X}_{2}(\mathrm{Q})$ & 3.9728 & 1 & 3.9728 & 440.2251 & 0.0303 \\
\hline Time of growth, $\mathrm{X}_{3}(\mathrm{~L})$ & 1.6013 & 1 & 1.6013 & 177.4382 & 0.0477 \\
\hline Time of growth, $\mathrm{X}_{3}(\mathrm{Q})$ & 0.3674 & 1 & 0.3675 & 40.7178 & 0.0989 \\
\hline $\mathrm{X}_{1} \mathrm{X}_{2}$ & 0.1866 & 1 & 0.1866 & 20.6795 & 0.1378 \\
\hline $\mathrm{X}_{1} \mathrm{X}_{3}$ & 0.0197 & 1 & 0.0197 & 2.1837 & 0.3787 \\
\hline $\mathrm{X}_{2} \mathrm{X}_{3}$ & 0.1935 & 1 & 0.1935 & 21.4390 & 0.1354 \\
\hline Lack of fit & 0.3990 & 2 & 0.1995 & 22.1092 & 0.1487 \\
\hline Pure Error & 0.0090 & 1 & 0.0090 & & \\
\hline Total & 15.5154 & 12 & & & \\
\hline
\end{tabular}

L: linear effect; Q: quadratic effect; \% of explained variance $=97.37 ; \%$ of maximum explained variance $=88.479 ; \mathrm{X}_{1}, \mathrm{X}_{2}, \mathrm{X}_{3}$ are variables described in Table 1 .

Table 2: ANOVA data for the production of $\beta-1,3-$ glucanases by Trichoderma harzianum Rifai PAMB-86, and test of significance for the regression coefficients.

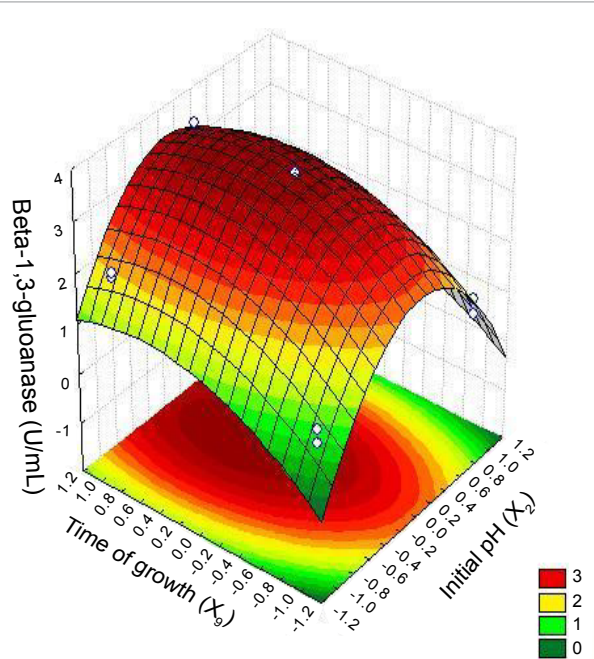

Figure 1: Response surface plot depicted as a 3-dimensional surface and contour showing the effect of $\beta$ - $(1 \rightarrow 3)$-glucanase production $\left(Y_{1}\right)$ by Trichoderma harzianum Rifai PAMB-86 as a function of initial $\mathrm{pH}\left(\mathrm{X}_{2}\right)$ and time of growth $\left(\mathrm{X}_{3}\right)$, at fixed aeration $\left(\mathrm{X}_{1}=1.5 \mathrm{vvm}\right)$ according to central composite design.

different $(1 \rightarrow 3)-\beta$-D-glucans as sole carbon sources. According to our experimental data, maximum $\beta$ - $(1 \rightarrow 3)$-glucanase production (3.7 U/ $\mathrm{ml}$ ) by $T$. harzianum Rifai PAMB-86 occurred within $5 \mathrm{~d}$ of growth, an initial pH of 5.5 and aeration of $1.5 \mathrm{vvm}$. This is a 3 -fold improvement over shake flask-grown cultures at the same concentration of botryosphaeran. The 3 -dimensional surface and contour plot showing the effect of $\beta$ - $(1 \rightarrow 3)$-glucanase production as a function of initial $\mathrm{pH}$ and time of growth is shown in Figure 1.

There were no significant observed alterations $(p<0.05)$ between the initial and final $\mathrm{pH}$ in the experimental runs. This behavior was also reported by Théodore \& Panda [22] with cultures of a T. harzianum strain using glucose as sole carbon source, and an initial $\mathrm{pH}$ of 4.7 was chosen as the best $\mathrm{pH}$ for optimal $\beta$ - $(1 \rightarrow 3)$-glucanase production. Donzelli et al. [25] evaluated growth and $\beta$ - $(1 \rightarrow 3)$-glucanase production by $T$. atroviride grown on scleroglucan $(\mathrm{a}(1 \rightarrow 3)(1 \rightarrow 6)-\beta$-D-glucan from Sclerotium glucanicum) and glucose as carbon sources, and verified a relationship between $\beta$ - $(1 \rightarrow 3)$-glucanase activities and initial $\mathrm{pH}$. An increase in initial $\mathrm{pH}$ from 5.5 to 6.5 increased enzyme production 16fold depending on other factors that were applied.

\section{Enzymatic hydrolysis of paramylon and pustulan}

ECF containing $\beta$-( $1 \rightarrow 3)$-glucanase activity was concentrated by lyophyllization and the re-solubilised enzyme preparation submitted to gel filtration chromatography. Fractionation revealed the presence of two enzyme fractions (F-I and F-II) hydrolyzing laminarin (a low branched $(1 \rightarrow 3)-\beta$-D-glucan with $(1 \rightarrow 6)-\beta$-D-glucosidic linkages, $\sim 5 \%)$. F-I contained mainly $\beta$ - $(1 \rightarrow 3)$-glucanase activity $(0.44 \mathrm{U} / \mathrm{ml})$ as well as $\beta$-glucosidase $(0.12 \mathrm{U} / \mathrm{ml})$ and $\beta$ - $(1 \rightarrow 6)$-glucanase activities $(0.24 \mathrm{U} / \mathrm{ml})$, while F-II contained lower $\beta-(1 \rightarrow 3)$-glucanase activity $(0.30 \mathrm{U} / \mathrm{ml})$, but no $\beta$ - $(1 \rightarrow 6)$-glucanase activity. Enzymes F-I and F-II exhibited broad substrate specificity (Table 3 ; relative activity assigned $100 \%$ to laminarin). The enzyme fractions showed no activity towards carboxymethylcellulose and dextran. F-II was not able to hydrolyse lichen pustulan and the oligosaccharides cellotriose and cellotetraose. Both fractions preferred laminaribiose and laminaritriose as substrates to laminarin, while F-I showed highest activity towards cellobiose and gentiobiose. 
Citation: Giese EC, Dekker RFH, Barbosa AM, da Silva MLC, da Silva R (2011) Production of $\beta$-(1,3)-glucanases by Trichoderma harzianum Rifai: Optimization and Application to Produce Gluco-oligosaccharides from Paramylon and Pustulan. Ferment Technol 1:102. doi:10.4172/21677972.1000102

Page 4 of 5

The $\beta$-glucanase complex from T. harzianum Rifai PAMB-86 was fractionated in attempts to separate the enzyme components so as to minimize attack on the oligosaccharides liberated during the early stages of hydrolysis of $\beta$-D-glucans by enzyme. Earlier studies using a crude enzyme preparation had demonstrated that gluco-oligosaccharides of DP $>3$ were largely absent from hydrolysates of laminarin and botryosphaeran [10]. To resolve and avoid this situation, we examined each enzyme fraction on its ability to hydrolyze paramylon and pustulan for the production of fragments of DP $>3$. Enzyme F-I degraded both $\beta$-D-glucans differently as judged by the array of hydrolysis products determined by HPAEC/PAD analysis (Table 4), while F-II hydrolysed paramylon in a similar manner to F-I. Glucose was released in relatively large amounts early during hydrolysis by both enzymes attacking paramylon, and the amounts of reducing sugars liberated increased with time. By $30 \mathrm{~min} \sim 15-20 \%$ of paramylon had been degraded by both enzymes. Under similar conditions, hydrolysis of pustulan by F-I showed that glucose too was rapidly released, and the reducing sugar content in the hydrolysates increased with time, and after 30 min, $\sim 2 \%$ of the pustulan was degraded. Enzymatic hydrolysates of paramylon by F-I and F-II contained laminaribiose and laminaritriose, but gentiobiose was absent, confirming that paramylon from Euglena gracilis did not carry glucose branches linked through $\beta$ - $(1 \rightarrow 6)$ bonds. Gluco-oligosaccharides of DP $\geq 4$ produced from paramylon decreased with time for both enzymes. F-I hydrolysates of pustulan contained gentiobiose and gluco-oligosaccharides of DP $\geq 4$ that increased with time of hydrolysis (Table 4). F-I thus appears to be an excellent enzyme preparation for the production of gluco-oligosaccharides of higher DP's from pustulan. The absence of laminaribiose and laminaritriose in F-I hydrolysates of pustulan confirmed that the pustulan of the lichen, Actinogyra muehlenbergii, did not carry any $\beta$ - $(1 \rightarrow 3)$-linked glucose residues.

Curdlan, a bacterial linear $(1 \rightarrow 3)-\beta$-D-glucan, was reported to be hydrolyzed by a crude $\beta$-( $1 \rightarrow 3)$-glucanase preparation from $T$. harzianum, and under the conditions, $80 \%$ of this polysaccharide was hydrolyzed [13]. $\beta$-Glucanases from Streptomyces sp. were also reported to degrade curdlan to mono-, di- and various lower oligosaccharides [15]. The crude $\beta$-glucanolytic enzyme preparation from T. harzianum Rifai revealed that these enzymes were also able to produce a broad

\begin{tabular}{|l|c|c|c|}
\hline \multirow{2}{*}{$\begin{array}{l}\text { Carbohydrate } \\
\text { substrates }\end{array}$} & \multirow{3}{*}{ Linkage type } & \multicolumn{2}{|c|}{ Relative enzyme activity (\%) } \\
\cline { 2 - 4 } & & Fraction-I & Fraction-II \\
\hline$\beta$-D-Glucans & \multicolumn{2}{|l|}{} \\
\hline Laminarin & $\beta-(1 \rightarrow 3)(1 \rightarrow 6)$ & 100 & 100 \\
\hline Botryosphaeran & $\beta-(1 \rightarrow 3)(1 \rightarrow 6)$ & 32 & 25 \\
\hline Paramylon & $\beta-(1 \rightarrow 3)$ & 27 & 31 \\
\hline Pustulan & $\beta-(1 \rightarrow 6)$ & 20 & 0 \\
\hline CMC 1 & $\beta-(1 \rightarrow 4)$ & 0 & 0 \\
\hline$\beta$-Gluco-oligosaccharides & & & \\
\hline Laminaribiose & $\beta-(1 \rightarrow 3)$ & 140 & 138 \\
\hline Laminaritriose & $\beta-(1 \rightarrow 3)$ & 133 & 121 \\
\hline laminaritetraose & $\beta-(1 \rightarrow 3)$ & 98 & 90 \\
\hline Gentiobiose & $\beta-(1 \rightarrow 6)$ & 124 & 11 \\
\hline Cellobiose & $\beta-(1 \rightarrow 4)$ & 127 & 5 \\
\hline Cellotriose & $\beta-(1 \rightarrow 4)$ & 48 & 0 \\
\hline Cellotetraose & $\beta-(1 \rightarrow 4)$ & 40 & 0 \\
\hline
\end{tabular}

Substrates $(1 \mathrm{mg} / \mathrm{ml})$ were incubated in $25 \mathrm{mM}$ sodium acetate buffer $(\mathrm{pH} 4.5)$ with each enzyme fraction ( $\mathrm{F}-\mathrm{I}$ or $\mathrm{F}-\mathrm{II} ; 1$ unit of activity) for $10 \mathrm{~min}$ at $50^{\circ} \mathrm{C}$. Aliquots were next withdrawn and assayed for reducing sugars and/or glucose. carboxymethylcellulose

Table 3: Relative rates of hydrolysis of $\beta$-D-glucans and gluco-oligosaccharides by $\beta$-glucanase fractions from Trichoderma harzianum Rifai PAMB-86.

\begin{tabular}{|c|c|c|c|c|c|c|c|c|}
\hline \multirow{2}{*}{ Substrate } & \multirow{2}{*}{$\begin{array}{c}\beta \text {-Glucanase } \\
\text { fraction }\end{array}$} & \multirow{2}{*}{$\begin{array}{l}\text { Time of } \\
\text { hydrolysis } \\
\text { (min) }\end{array}$} & \multirow{2}{*}{$\begin{array}{c}\text { Reducing } \\
\text { sugars } \\
(\mu \mathrm{g} / \mathrm{ml})\end{array}$} & \multicolumn{5}{|c|}{$\begin{array}{l}\text { Hydrolysis products }{ }^{1} \\
\text { (Relative amounts, \%) }\end{array}$} \\
\hline & & & & $\mathbf{G}_{1}$ & $\mathbf{G}_{2 \mathrm{G}}$ & $\mathbf{G}_{2 \mathrm{~L}}$ & $\mathbf{G}_{3 \mathrm{~L}}$ & $D P \geq 4$ \\
\hline \multirow{8}{*}{ Paramylon } & \multirow{4}{*}{ Fraction I } & 5 & $110 \pm 8$ & 82 & $\underset{2}{N D}$ & 16 & 0.2 & 2 \\
\hline & & 10 & $140 \pm 11$ & 82 & ND & 15 & 0.3 & 3 \\
\hline & & 20 & $142 \pm 10$ & 77 & ND & 20 & 0.3 & 3 \\
\hline & & 30 & $218 \pm 6$ & 67 & ND & 32 & 0.6 & 1 \\
\hline & \multirow{4}{*}{ Fraction II } & 5 & $82 \pm 8$ & 69 & ND & 22 & 0.5 & 9 \\
\hline & & 10 & $121 \pm 11$ & 73 & ND & 18 & 0.3 & 9 \\
\hline & & 20 & $131 \pm 12$ & 79 & ND & 19 & ND & 2 \\
\hline & & 30 & $168 \pm 7$ & 75 & ND & 24 & ND & 1 \\
\hline \multirow{4}{*}{ Pustulan } & \multirow{4}{*}{ Fraction I } & 5 & $8 \pm 0.5$ & 67 & 22 & ND & ND & 11 \\
\hline & & 10 & $15 \pm 0.9$ & 65 & 25 & ND & ND & 10 \\
\hline & & 20 & $19 \pm 0.9$ & 62 & 7 & ND & ND & 31 \\
\hline & & 30 & $25 \pm 0.8$ & 50 & 23 & ND & ND & 27 \\
\hline
\end{tabular}

Enzymatic hydrolysis of paramylon and pustulan (1 g/l; solubilised by autoclaving was conducted in $20 \mathrm{ml}$ solution ( $25 \mathrm{mM}$ sodium acetate buffer, $\mathrm{pH} 4.5$ ) using 1 unit of each enzyme fraction (F-I, F-II; activity measured against laminarin) at $40^{\circ} \mathrm{C}$ ${ }^{1} G_{1}$, glucose; $G_{2 G}$, gentiobiose; $G_{2 L}$, laminaribiose; $G_{3 L}$, laminaritriose; $D P$, degree of polymerization; ${ }^{2} \mathrm{ND}$, not detectable

Table 4: HPAEC-PAD analysis of enzymatic hydrolysates of paramylon and pustulan using enzyme fractions F-I and F-II from Trichoderma harzianum Rifai PAMB-86.

range of products from botryosphaeran in short incubation times [10] with only tetrasaccharides as the highest DP liberated. Grandpierre et al. [26] observed that the rapid release of glucose could inhibit enzyme action on curdlan.

Fungal $\beta$-( $1 \rightarrow 6)$-glucanases are associated with $\beta$ - $(1 \rightarrow 3)$-glucanase activities in many microorganisms [16]. Reese et al. [27] observed gentiotetraose, gentiotriose, gentiobiose and glucose as hydrolysis products, and verified that these enzymes acted in an endo-glucanase manner. The $\beta$ - $(1 \rightarrow 6)$-glucanases from Acremonium sp. IMI 383068 showed an improvement of hydrolysis products from pustulan when the incubation time was increased [28]. Wu et al. [29] used a $\beta-(1 \rightarrow 6)-$ glucanase preparation from Streptomyces rochei to hydrolyze pustulan from the lichen, Umbilicaria papullose, and observed a range of oligosaccharides formed within 10 min of incubation.

Analysis of the products obtained after incubation of the $\beta$-Dglucans, paramylon and pustulan, with $\beta$-glucanases from T. harzianum Rifai PAMB-86 revealed more information about the specificity of the enzymes produced by this fungus, and this information can be useful in further studies to optimize gluco-oligosaccharide production.

In conclusion, the $\beta$-glucanases from T. harzianum Rifai PAMB86 showed maximal enzyme titres at 5 days fermentation, initial $\mathrm{pH}$ 5.5 and aeration of $1.5 \mathrm{vvm}$. This enzyme complex was demonstrated to be useful in the production of gluco-oligosaccharides from algal paramylon and lichen pustulan, which may find applications as prebiotics (nutraceuticals) and modifiers of immunological activities.

\section{Acknowledgements}

The authors are grateful to CAPES, FAPESP, Fundação Araucária do Paraná (Brazil), and Lakehead University for financially supporting this work. EC Giese gratefully acknowledges FAPESP for a post-graduate scholarship. LG Covizzi is thanked for assisting with some experiments.

\section{References}

1. Chen J, Seviour R (2007) Medicinal importance of fungal $\beta-(1 \rightarrow 3)$, $(1 \rightarrow 6)$-glucans. Mycol Res 111: 635-652.

2. Maltese A, Borzacchiello A, Mayol L, Bucolo C, Maugeri F, et al. (2006) 
Citation: Giese EC, Dekker RFH, Barbosa AM, da Silva MLC, da Silva R (2011) Production of $\beta$-(1,3)-glucanases by Trichoderma harzianum Rifai: Optimization and Application to Produce Gluco-oligosaccharides from Paramylon and Pustulan. Ferment Technol 1:102. doi:10.4172/21677972.1000102

Page 5 of 5

Novel polysaccharide-based viscoelastic formulations for ophthalmic surgery: Rheological characterization. Biomaterials 27: 5134-5142.

3. Viñarta SC, Molina OE, Figuero LIC, Fariña JI (2006) A further insight into the practical applications of exopolysaccharides from Sclerotium rolfsii. Food Hydrocol 20: 619-629.

4. Barbosa AM, Dekker RFH, Giese EC (2010) Bioactive Oligosaccharides: Production, Biological Functions and Potential Commercial Applications. Nova Science Publishers, New York, USA.

5. Vos AP, M'Rabet L, Stahl B, Boehm G, Garssen J (2007) Immune-modulatory effects and potential working mechanisms of orally applied nondigestible carbohydrates. Crit Rev Immunol 27: 97-140.

6. Barsanti L, Vismara R, Passarelli V, Gualtieri P (2001) Paramylon ( $\beta-1,3$ glucan) content in wild type and WZSL mutant of Euglena gracilis. Effects of growth conditions. J Appl Phycol 13: 59-65.

7. Iacomini M, Gorin PJG, Baron M, Tulloch AP, Mazurek M (1988) Nove D-glucans obtained by dimethylsulfoxide extraction of the lichens Letharia vulpina, Actinogyra muehlenbergii, and an Usnea sp. Carbohydr Res 176: $117-$ 126.

8. Sassaki GL, Ferreira JC, Glienke-Blanco C, Torri G, Toni F, et al. (2002) Pustulan and branched $\beta$-galactofuranan from the phytopathogenic fungus Guignardia citricarpa, excreted from media containing glucose and sucrose. Carbohydr Pol 48: 385-389.

9. Vasconcelos AF, Monteiro NK, Dekker RF, Barbosa AM, Carbonero ER, et al. (2008) Three exopolysaccharides of the $\beta$-(1 $\rightarrow 6)$-D-glucan type and a $\beta-(1 \rightarrow 3 ; 1 \rightarrow 6)$-D-glucan produced by strains of Botryosphaeria rhodina isolated from rotting tropical fruit. Carbohydr Res, 343: 2481-2485

10. Giese EC, Covizzi LG, Dekker RFH, Monteiro NK, Corradi da Silva ML, et al. (2006) Enzymatic hydrolysis of botryosphaeran and laminarin by $\beta-1,3$ glucanases produced by Botryosphaeria rhodina and Trichoderma harzianum Rifai. Process Biochem 41: 1265-1271.

11. Pitson SM, Seviour RJ, McDougall BM (1997) Production of $\beta$-glucan degrading enzymes by Acremonium and Cephalosporium species. Mycol Res 101: 153158.

12. Pang Z, Otaka K, Maoka T, Hidaka K, Isijima S, et al. (2005) Structure of $\beta$-glucan oligomer from laminarin and its effect on human monocytes to inhibit the proliferation of U937 cells. Biosci Biotechnol Biochem 69: 553-558.

13. Kadi N, Crouzet J (2008) Transglycosylation reaction of endoxylanase from Trichoderma longibrachiatum. Food Chem 106: 466-474.

14. Sutherland IW (1999) Polysaccharases for microbial exopolysaccharides. Carbohydr Res 38: 319-328.

15. Bielecki S, Galas E (1991) Microbial $\beta$-glucanases different from cellulases. Crit Rev Biotechnol 10: 275-304.

16. Pitson SM, Seviour RJ, McDougall BM (1993) Non-cellulolytic funga $\beta$-glucanases: Their physiology and regulation. Enz Microb Technol 15: 178192.
17. Chen LL, Zhang M, Zhang DH, Chen XL, Sun CY, et al. (2009) Purification and enzymatic characterization of two $\beta$-endoxylanases from Trichoderma $\mathrm{sp}$ K9301 and their actions in xylo-oligosaccharide production. Bioresour Techno 100: $5230-5236$

18. Barbosa AM, Steluti RM, Dekker RF, Cardoso MS, Corradi da Silva ML (2003) Structural characterization of botryosphaeran: a $(1 \rightarrow 3 ; 1 \rightarrow 6)-\beta-D-g l u c a n$ produced by ascomyceteous fungus, Botryosphaeria sp. Carbohydr Res 338 1691-1698.

19. Vogel HJ (1956) A convenient growth medium for Neurospora crassa. Microbia Gen Bull 13: 42-43

20. Somogyi MA (1945) A new reagent for determination of sugars. J Biol Chem 160: 61-68.

21. Aires RS, Steindorff AS, Ramada MHS, Siqueira SJL, Ulhoa CJ (2012) Biochemical characterization of a $27 \mathrm{kDa} 1,3-\beta-D-g l u c a n a s e$ from Trichoderma asperellum induced by cell wall of Rhizoctonia solani. Carbohydr Polym 87 1219-1223.

22. Théodore K, Panda T (1995) Application of response surface methodology to evaluate the influence of temperature and initial $\mathrm{pH}$ on the production of $\beta-1,3$ glucanase and carboxymethylcellulase from Trichoderma harzianum. Enz Microb Technol 17: 1043-1049.

23. Giese EC, Covizzi LG, Borsato D, Dekker RFH, Corradi da Silva ML, et al (2005) Botryosphaeran, a new substrate for the production of $\beta-1,3$-glucanases by Botryosphaeria rhodina and Trichoderma harzianum Rifai. Process Biochem 40: $3783-3788$

24. Giese EC, Dekker RFH, Scarminio IS, Barbosa AM, Silva R (2011) Comparison of $\beta-1,3$-glucanase production by Botryosphaeria rhodina MAMB-05 and Trichoderma harzianum Rifai and its optimization using a statistical mixturedesign. Biochem Eng J 53: 239-243.

25. Donzelli BGG, Siebert KJ, Harman GE (2005) Response surface modeling of factors influencing the production of chitinolytic and beta-1,3-glucanolytic enzymes in Trichoderma atroviride strain P1. Enz Microb Technol 37: 82-92.

26. Grandpierre C, Janssen H-G, Laroche C, Michaud P, Warrand J (2008) Enzymatic and chemical degradation of curdlan targeting the production of $\beta-(1,3)$ oligoglucans. Carbohydr Polym 71: 277-286.

27. Reese ET, Parrish FW, Mandels M (1962) $\beta-D-1,6$ glucanases in fungi. Can J Microbiol 8: 327-334.

28. Jayus, McDougall BM, Seviour RJ (2001) Purification and properties of $(1 \rightarrow 6)-\beta$-glucanase from Acremonium sp. IMI 383068. Enz Microb Technol 29 194-200.

29. Wu H, Shimoi $H$, Ito $K$ (2002) Purification and characterization of $\beta-1,6$ glucanase of Streptomyces rochei application in the study of yeast cell wall proteins. Biosc Biotechnol Biochem 66: 2515-2519.

30. Bruns RE, Scarminio IS, Barros Neto B (2006) Statistical Design-Chemometrics. Elsevier. 